\title{
Historical perspectives of The American Association for Thoracic Surgery: Thomas H. Burford (1907-1977)
}

\author{
Shoichi Okada, MD, and Marc R. Moon, MD
}

Thomas Hannahan Burford, 51st president of The American Association for Thoracic Surgery (AATS), was a native of New Franklin in central Missouri, born on December 23, 1907. Burford's nickname "Black Tom" originally referred to his jet-black hair but persisted throughout his career because of his strict discipline and polarizing military temperament. ${ }^{1,2}$ Black Tom spent much of his youth hunting and fishing the tributaries of the Missouri River, experiences that instilled in him a rugged, self-sufficient character and pioneering innovativeness that eventually propelled his career in the relatively underdeveloped specialty of thoracic surgery during the mid-twentieth century. He also inherited a thorough admiration and fascination with trains and railroads from his father, who was a conductor on the Katy (Missouri-Texas) Line.

Burford received his undergraduate degree from the University of Missouri-Columbia and completed medical school at Yale University in 1936. Burford received his general and thoracic surgery training at Barnes Hospital, Washington University. Burford and Lawrence Shefts were the first residents in the newly created, formal 2-year thoracic residency organized by Dr Evarts Graham (10th AATS president) and the program director Dr Brian Blades (37th AATS president) in 1940. The Washington University thoracic residency was the second such program in the country; John Alexander (17th AATS president) had established the first at the University of Michigan.

Not long after finishing his training, Burford entered the Army and was assigned to the Second Auxiliary Surgical Group, which comprised 27 general surgeons and 5 thoracic surgeons, including Burford and Shefts, Paul Samson (48th AATS president), Lyman Brewer (54th AATS president), and Reeve Betts, considered by many to be the father of cardiothoracic surgery in India. The "Second Aux" was under the ultimate control of Colonel Edwin Churchill (28th AATS president), who left his post as Chief of Surgery at the Massachusetts General Hospital to serve as Chief Consultant in Surgery for the Mediterranean Theatre of Operations. Initially, there was a strong belief among the regular

\footnotetext{
From the Division of Cardiothoracic Surgery, Washington University School of Medicine, St Louis, Mo.

Disclosures: Authors have nothing to disclose with regard to commercial support.

Received for publication Nov 14, 2012; accepted for publication Dec 5, 2012; available ahead of print Jan 10, 2013.

Address for reprints: Marc R. Moon, MD, Joseph C. Bancroft Professor of Surgery, Division of Cardiothoracic Surgery, Washington University School of Medicine, 660 S. Euclid Ave, Box 8234, St Louis, MO 63110 (E-mail: moonm@wustl.edu). J Thorac Cardiovasc Surg 2013;145:621-5 $0022-5223 / \$ 36.00$

Copyright (c) 2013 by The American Association for Thoracic Surgery http://dx.doi.org/10.1016/j.jtcvs.2012.12.017
}

army brass that thoracic surgery was principally concerned with evacuation of pus from the thoracic cavity and belonged in the division of "septic surgery.", 2 This had been the case in World War I, during which time Dr Graham and the Empyema Commission faced postpneumonic empyema, most often the result of measles or influenza rather than high-velocity missile injuries. After much debate, the group of 5 eventually convinced Churchill to establish a dedicated Thoracic Surgery Center on a trial basis.

Because of his medical military experience, Burford was a major contributor to the Surgeon General's multivolume textbook series "Surgery in World War II," published in the mid-1960s." ${ }^{3,4}$ The 2 volumes dedicated to thoracic surgery functioned as the treatment manuals for military surgeons during the Vietnam War. The first volume was dedicated to administrative considerations and patient flow routines, and the second volume focused on treatment of specific wounds and complications related to thoracic injuries. The treatment regimen for many important facets of thoracic disease emanated from Burford's surgical group during the Second World War, including "wet lung" (posttraumatic respiratory insufficiency), ${ }^{5}$ the importance of appropriate resuscitation before thoracotomy, selective thoracotomy in the field, selective removal of traumatic foreign bodies, and Burford's most important personal contribution, decortication for hemothorax.

Major Burford's first assignment early in 1943 was in Bou Hanifia, Algeria, to support the Tunisian landings. By spring, the Thoracic Surgery Center was receiving heavily infected thoracic casualties, both US Army personnel and German prisoners of war. ${ }^{6}$ At the time, the policy of delayed evacuation of hemothorax led to debilitating empyema in many cases. Retained clot with incomplete reexpansion served as a fertile breeding ground for bacteria. The World War I approach to peripneumonic empyema was one of watchful waiting because of fears of mediastinal shift and conversion of a local to generalized infection. Surgeons waited until an abscess formed and then performed chronic drainage with rib resection, which often led to long-term debilitation and chronic invalidism. In World War II, the British had experience with "turning out the clot," in which they performed a limited thoracotomy to scoop out a retained hemothoracic empyema, but this approach was still associated with $20 \%$ mortality and $55 \%$ incidence of chronic empyema.

The British emphasized the firmness of the peel during surgery, to which Burford speculated, "It might be worthwhile to cut through it and see what lay underneath." ${ }^{, 7}$ Burford then conducted a not-so-randomized controlled trial on 2 patients with almost identical degrees of organized 

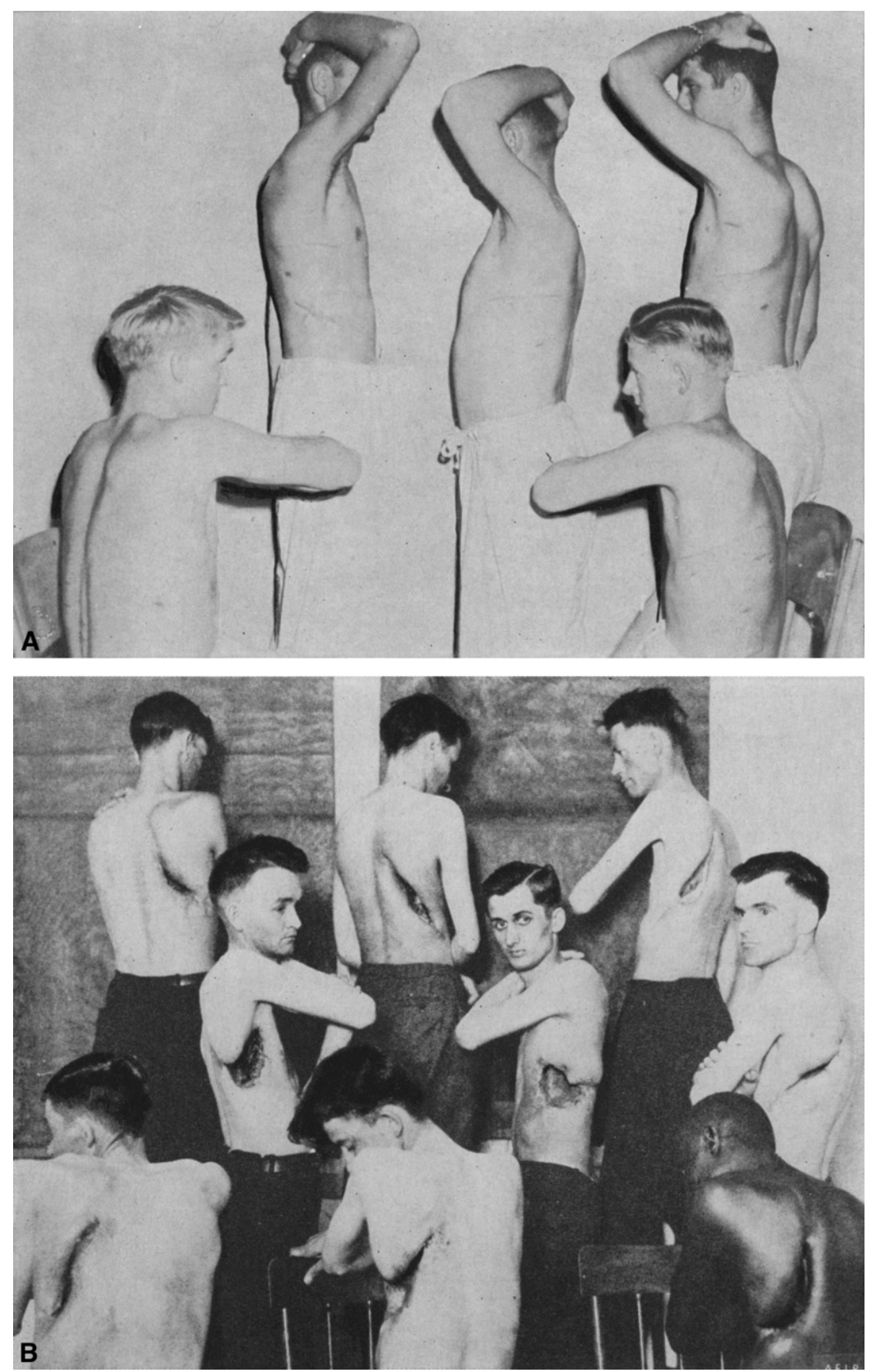

FIGURE 1. During World War II, healthy soldiers (A) after decortication compared with chronic invalids (B) after "conservative" treatment of chronic empyema. ${ }^{6}$

hemothoraces 5 weeks post-injury. The first subject was an American soldier who received traditional management. His recovery was described as less than ideal. The second subject was a German prisoner who was treated by thoracotomy and decortication using a technique similar to that described by Delorme ${ }^{8} 50$ years earlier. When Burford cut into the peel, he was delighted to find normal lung herniating through the opening, which led to total reexpansion and an excellent recovery. With this dramatic paradigm shift in the treatment of retained hemothorax, Burford and the others were able to help many wounded soldiers who would otherwise not have survived or who would have been severely crippled and disfigured by this condition. Figure 1 compares a group of soldiers from World War I with disfiguring chronic empyema cavities with a group from World War II who experienced complete recovery after Burford's 


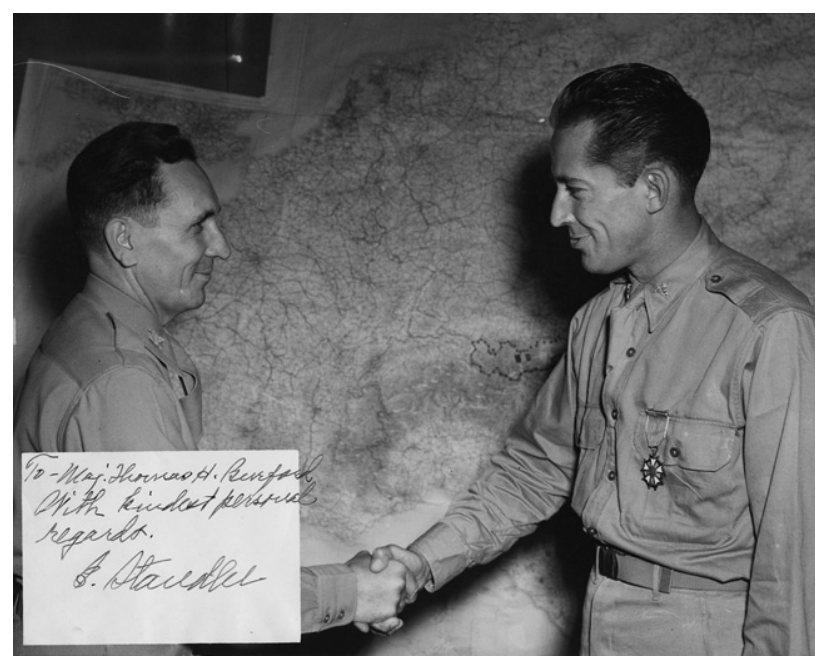

FIGURE 2. Colonel Earle Standlee, Chief Surgeon of Mediterranean Theatre of Operations, congratulates Major Burford after presenting him the Legion of Merit for "exceptionally meritorious conduct in the performance of outstanding services in North Africa and Italy from May 22, 1943, to August 1, 1945." Photograph courtesy of Historical Archives, Bernard Becker Medical Library, Washington University School of Medicine.

lifesaving battlefield innovation. Dr Burford was awarded the Italian Medal of Valor and the US Army Legion of Merit Award for his bold and imaginative surgical contributions and unparalleled military leadership (Figure 2$)^{1}$
At War's end, Burford returned to the Chest Service at Washington University in 1946 and became the head of the Division of Thoracic and Cardiovascular Surgery after Graham's retirement in 1951 (Figure 3). Thoracic surgery had entered an era of rapid development during Burford's tenure, with new frontiers blossoming in all aspects of diseases of the chest. Burford was the first to champion early surgery for coarctation of the aorta in neonates and developed the management regimen for caustic burns of the esophagus with stricture. ${ }^{9,10}$ Among the monumental legacies Burford left thoracic surgery, some are tucked away in the corners of his home institution. The tonsil clamp, one of the most widely used instruments in the operating room, exemplifies the magnitude of Burford's mark. This instrument dons a unique alias at Washington University, the "Burlisher," an eponym created in honor of 2 of our great surgical ancestors, Thomas Burford and Carl Lisher. Burford also was the inaugural vice president of the Society of Thoracic Surgeons and the society's second president, one of only a handful to become president of both major American thoracic surgical groups (Thomas B. Ferguson, 62nd AATS president, was the second from Washington University to accomplish this honor).

Despite his numerous clinical contributions to the field, Dr Burford was most proud of, yet humbled by, those he trained. ${ }^{11}$ "I have never transplanted a heart," he confessed.

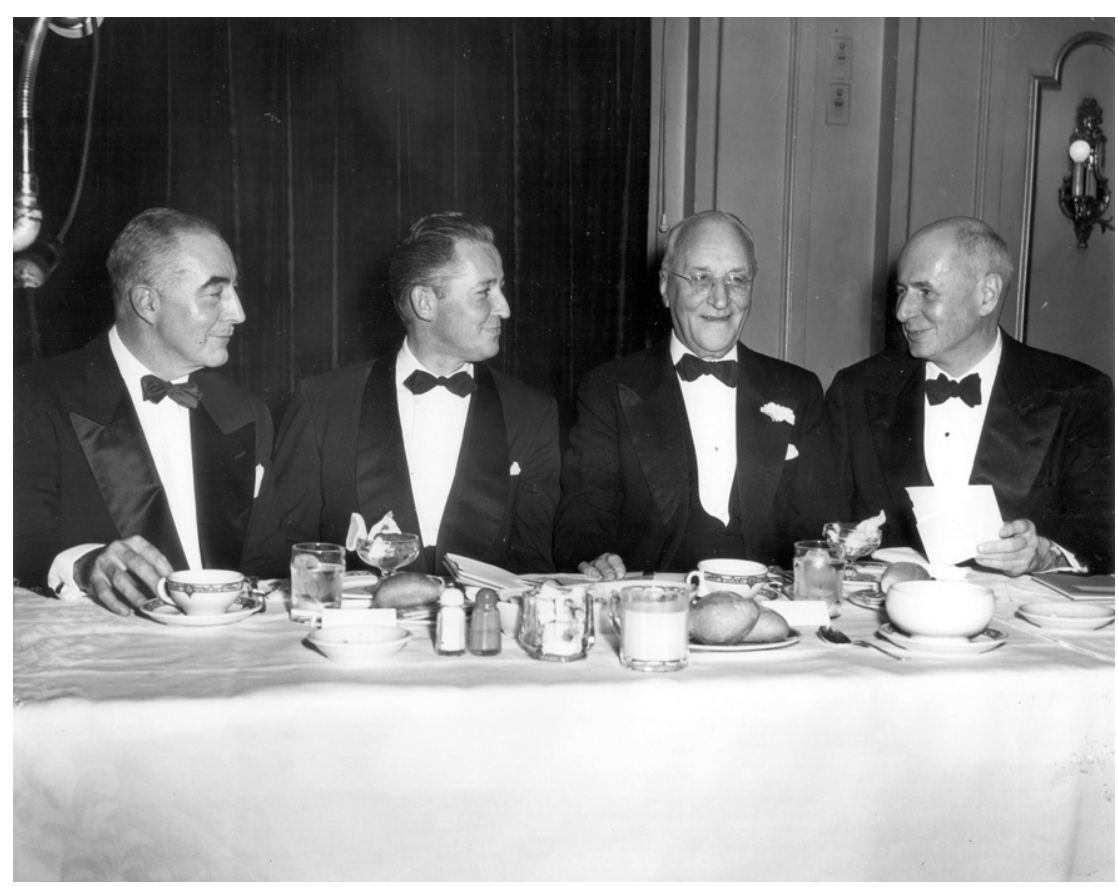

FIGURE 3. Brian Blades, Thomas Burford, Evarts Graham, and Edwin "Pete" Churchill at Dr Graham's retirement party as Chief of Surgery at Washington University at the Gold Room of the Hotel Jefferson in St Louis, November 30, 1951. The transcript of the remarks from this tribute and Graham's retirement address were published in the Annals of Surgery in July 1952. Photograph courtesy of Historical Archives, Bernard Becker Medical Library, Washington University School of Medicine. 
"I have not even attempted a triple valve replacement or a vein graft to the coronary arteries. All of those feats, however, have been accomplished by my trainees." ${ }^{12}$ Burford often quoted Cicero's "Not only is there an art in knowing a thing, but also a certain art in teaching it," and he was a strong proponent of hands on training. "I firmly believe that daily contact with the chief at the operating table is the best teaching exercise ever devised in surgery. A modern resident needs little or no instruction in anatomy. What he needs is the subtle, indefinable 'how' of the master."12

Education was of paramount importance to Burford, a passion he adopted from his mentor, Dr Graham. In 1971, during his presidential address to The American Association for Thoracic Surgery entitled "From Whence to Whither," Burford summarized his thoughts and recommendations on education and "being the Chief." $12 \mathrm{He}$ emphasized discipline in training, and his philosophy was that on a scale of priorities, "Being right is more important than being liked." ${ }^{12}$ His fervent pursuit of excellence in academic cardiothoracic surgery was feared and misunderstood by some, but the results were undeniable and respected by all. Burford's high expectations for residents began in the interview phase. His selection criteria included applicants who were "clean-shaven, well-groomed, hardworking, and expected to work harder and longer than the Chief." ${ }^{2} \mathrm{He}$ also recommended we avoid the verbose noting that, "Too often, a glib tongue represents a compensatory adaptation for clumsy hands." 12

Dr Burford felt strongly that "A Chief must above all earn respect. It cannot be commanded or demanded." 12 As a consequence, he led by example. During his tenure, he trained 50 or so residents who by all accounts had developed a "fierce loyalty" to the chief. ${ }^{1}$ Dr Burford expected nothing less than unconditional effort from his pupils, but he felt strongly that we should "Be restrained and totally private with rebuke and criticism. It is a weak man who attempts to glorify his own image by publicly stripping another of his dignity." ${ }^{12}$ Burford stepped down as chief after 17 years in 1968, still in his surgical prime. "Go out a winner," he proclaimed, "qualified younger men should be entrusted with the major responsibilities of training and teaching. They have the zest and the energy to inspire and far more patience with immaturity." ${ }^{12}$ He continued his clinical practice until his terminal illness in 1977.

Clarence Weldon who succeeded Burford as chief described him as, "Strikingly handsome, precise, dramatically flamboyant, and given to caustic wit." 13 Burford was also a devoted family man, but he kept that to himself. Burford spent all of his free time with his wife, Louise Miller Burford, and his 2 children in their country home, bestowing them with the same passion for the outdoors that he developed as a youth..$^{1,2,11}$ Burford was an avid smoker, as was his mentor Dr Graham, and both died as a consequence of their habit; Graham died of lung cancer in 1957, and
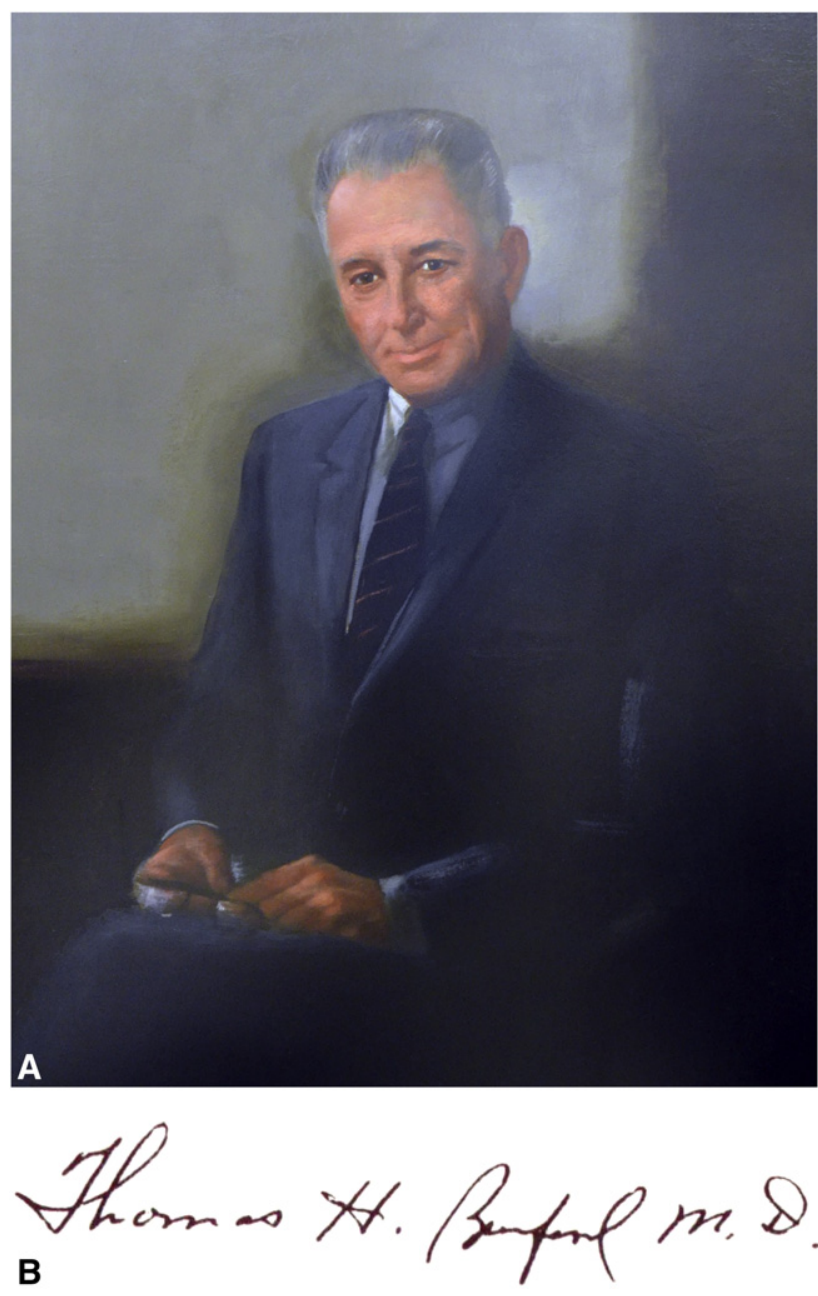

FIGURE 4. A, Portrait of Thomas H. Burford that hangs in the Becker Memorial Library at Washington University in St Louis. B, Signature of Thomas H. Burford. Courtesy of Historical Archives, Bernard Becker Medical Library, Washington University School of Medicine.

Burford died of cerebral vascular disease and emphysema. However, Burford, unlike Graham, ${ }^{14}$ was never willing to accept the causality of cigarette smoking on cancer, conjecturing that tumor biology was far more complex than proposed at the time to explain the relationship. Burford's views on the relationship between smoking and lung cancer attracted national attention, not only among the medical community but also among the general public. He was an advocate for the cigarette companies and served as an expert witness in defense of the tobacco industry. In 1965, he summarized his thoughts during a Senate Commerce Committee hearing on cigarette labeling: "I do not believe that lung cancer is caused by cigarette smoking, and I do not believe that smoking is responsible for any shortening of life." 15

With tongue in cheek, Burford once insisted that he had "mustered much meekness" in his lifetime, but instead of inheriting the earth as his mother had suggested, he was rewarded "only by insomnia, dyspepsia, and a fine 
tremor."11,12 Those who knew Dr Burford would never have labeled him as meek. Strength of conviction and total dedication to his vocation were his defining characteristics. Thomas Burford was a born leader with proven results, the likes of which, for better or for worse, we will almost certainly never see again in thoracic surgery (Figure 4).

\section{References}

1. Ferguson TB. In memoriam. Thomas Hannahan Burford (1907-1977). J Thorac Cardiovasc Surg. 1977;74:947-8.

2. Brewer LA. Tribute. Thomas Hannahan Burford, 1908-1977. Ann Thorac Surg. 1978;25:1-2.

3. Coates JB, ed. Medical Department, US Army. Surgery in World War II. Thoracic Surgery Volume I. Washington, DC: Office of the Surgeon General; 1963.

4. Ahnfeldt AL, ed. Medical Department, US Army. Surgery in World War II. Thoracic Surgery Volume II. Washington, DC: Office of the Surgeon General; 1965.

5. Burford TH, Burbank B. Traumatic wet lung; observations on certain physiologic fundamentals of thoracic trauma. J Thorac Surg. 1945;14:415-24.
6. Burford TH. Medical Department, US Army. Hemothorax and hemothoracic empyema. In: Ahnfeldt AL, ed. Surgery in World War II. Thoracic Surgery Volume II. Washington, DC: Office of the Surgeon General; 1965:237-324.

7. Berry FB. Medical Department, US Army. Historical note. In: Coates JB, ed. Surgery in World War II. Thoracic Surgery Volume I. Washington, DC: Office of the Surgeon General; 1963:3-49.

8. Delorme E. Nouuveau traitement des empyemes chroniques. Gaz Hop Civ Milit. 1894;67:94-6.

9. Burford TH, Ferguson TB, Goldring D, Behrer MR. Coarctation of the aorta in infants: a clinical and experimental study. J Thorac Cardiovasc Surg. 1960;39:47-59.

10. Burford TH, Webb WR, Ackerman L. Caustic burns of the esophagus and their surgical management; a clinico-experimental correlation. Ann Surg. 1953;138:453-60.

11. Schwartz HG. Eulogy for Tom Burford. May 20, 1977. Historical Archives, Bernard Becker Medical Library, Washington University School of Medicine.

12. Burford TH. From whence to whither. J Thorac Cardiovasc Surg. 1971;62: 167-75.

13. Weldon CS. In memoriam. Thomas H. Burford. May 1977. Historical Archives, Bernard Becker Medical Library, Washington University School of Medicine.

14. Wynder EL, Graham EA. Tobacco smoking as a possible etiologic factor in bronchiogenic carcinoma; a study of 684 proved cases. J Am Med Assoc. 1950;143: 329-36.

15. Statement of Thomas H. Burford, MD, Congressional Hearings on Cigarette Labelling. Spring 1965. Historical Archives, Bernard Becker Medical Library, Washington University School of Medicine. 